\title{
Common Determinant and Prevention Strategies of Cancer in the Pacific Countries: A Systematic Review
}

\author{
Masoud Mohammadnezhad ${ }^{1, ~ *, ~ N a s s e r ~ S a l e m ~ A l q a h t a n i ~}{ }^{2}$, Mosese Salusalu ${ }^{1}$, Adam Konrote ${ }^{1}$ \\ ${ }^{1}$ Department of Public Health, Fiji National University, Suva, Fiji \\ ${ }^{2}$ Department of Clinical Nutrition, Northern Borders University, Arar, Saudi Arabia
}

Email address:

masoud.m@fnu.ac.fj (M. Mohammadnezhad)

${ }^{*}$ Corresponding author

\section{To cite this article:}

Masoud Mohammadnezhad, Nasser Salem Alqahtani, Mosese Salusalu, Adam Konrote. Common Determinant and Prevention Strategies of Cancer in the Pacific Countries: A Systematic Review. European Journal of Preventive Medicine. Vol. 5, No. 5, 2017, pp. 51-59. doi: 10.11648/j.ejpm.20170505.11

Received: June 26, 2017; Accepted: July 13, 2017; Published: August 1, 2017

\begin{abstract}
Cancer is the second leading cause of death worldwide which accounts for 8.2 million deaths each year. Cancer is also one of the important public health priorities in Pacific. Developing preventive strategies can help people to reduce the burden of this disease. As there is no any systematic review done till now, this syntactic review study is aimed to understand the common determinants of cancer and the preventive strategies in Pacific. This study applied the Cochrane library guideline of conducting systematic review. Five more frequent databases were used to find relevant studies. Using keywords which were developed based on the aim of the study, and also inclusion and exclusion criteria, articles were searched and reviewing the articles was conducted by two independent coders. After removing duplicated studies, three steps ware applied to achieve the final studies. A data extension sheet was developed and the data were analyzed using a descriptive statistical analysis. Overall, 36 studies were included in the study. USA Pacific countries such as Hawaii had highest number of studies (44\%) which followed by South Pacific (33.4\%) and Asia Pacific (16.6\%) countries. Majority of studies (86\%) were applied the quantitative design and $14 \%$ were used the qualitative design. The common determinants for cancer were categorized into three areas including the services factors, detection and treatment factors, and individual factors. The most common prevention strategies for cancer were improving health care system such as screening, intensive follow up and surveillance, health education and awareness, policy implementation, and immunization. The results of this study highlighted the most common determinants of cancer and the preventive strategies in Pacific. Considering the results of this study, the health specialist in PICs needs to address all these identified common determinants of cancer among cancer patients from the pacific in the past in order to come up with new strategies or prevention for cancer in the future.
\end{abstract}

Keywords: Determinants, Preventive Strategies, Cancer, Pacific, Systematic Review

\section{Introduction}

The World Health Organization (WHO) defines cancer as an uncontrolled growth and spread of cells that can affect almost any part of the body [1]. Cancer is not just one disease but a large group of almost 100 diseases [2]. In addition, there are several types of cancer which include Carcinoma, Sarcoma, Leukaemia, Lymphoma and multiple myeloma, and malignancy [3]. Cancer is not refined and can affect everyone-young and old, rich and poor, men, women and children [1]. Hence it is an issue of grave concern.
Cancer is the second leading cause of death worldwide which accounts for 8.2 million deaths each year [4]. In 2015, 1.69 million deaths accounted for lung cancer, 788,000 deaths for Liver, 774,000 for colorectal, 754,000 for stomach, and 571, 000 for breast cancer. Cancer represents a tremendous burden on patients, families, and societies worldwide [5]. Cancer burden worldwide expected to continue to increase in the future. In the Pacific countries, Papua New Guinea among all the Pacific islands has the highest numbers of deaths which accounted 546 followed by Fiji 390 [1].

According to WHO cancer has been associated with 
certain factors such as tobacco farming and use, dietary patterns, and alcohol consumption [6]. In addition, no access to quality health care, poverty, no health insurance, and culture are some other common determinants of cancer [7].

Despite this certain forms of cancer have been found to be preventable [8]. It was found that between $30 \%$ and $50 \%$ of cancer deaths could be prevented by avoiding risk factors, including tobacco products, reducing alcohol consumption, maintaining a healthy body weight, exercising regularly and addressing infection-related risk factors [6, 9]. Health promotion activities and strategic plans are the only two ways that will prevent cancer and improve the health of all Pacific Islanders in the future.

To reduce the tremendous burden from happening, it is better to identify the determinants of cancer in order to prevent cancer, promote cancer awareness and control cancer epidemic through-out the whole Pacific countries. This systematic review, regarding the determinants and prevention for cancer is very important, as there has been no review done on this in the Pacific recently, and this will be the first. The purpose of this systematic review is to identify the common determinants for cancer and prevention for cancer in the pacific.

\section{Methods}

This systematic review was conducted considering the guidelines provided by the Cochrane library using five frequently used databases by similar studies. The most common journals used included MEDLINE, Scopus, EMBASE, WEB of Science Electronic Database, Pubmed, and PsychINFO. To obtain more relevant studies, key words such as "determinants", "prevent*", "strategy", "cancer", "Pacific", "treatment" were used and combined using AND/OR to increase the search scope. Studies selected were published from $1^{\text {st }}$ January 2000 to $1^{\text {st }}$ January 2017 and were written in the English Language. Non English studies and those which did not fit the description of the key words were excluded.

Two independent reviewers scanned the titles of all selected studies and duplicated studies were omitted using the End Note software. Following this the reviewers analyzed the abstract sections of the studies and irrelevant studies were omitted. The remaining studies texts were then fully reviewed and any studies which were deemed irrelevant to the topic were removed (Figure 1). Thirty three studies were selected after reviewing the full text of the studies. The reviewers then went through the bibliography sections of the selected studies to obtain other relevant studies (3 studies). Finally 36 studies were included in the study.

Using the remaining studies a data extraction sheet was formulated (Table 4) which included the study information, population, methods and study results. Using the extraction sheet a descriptive analysis was made and the frequency and percentages of the results were reported.

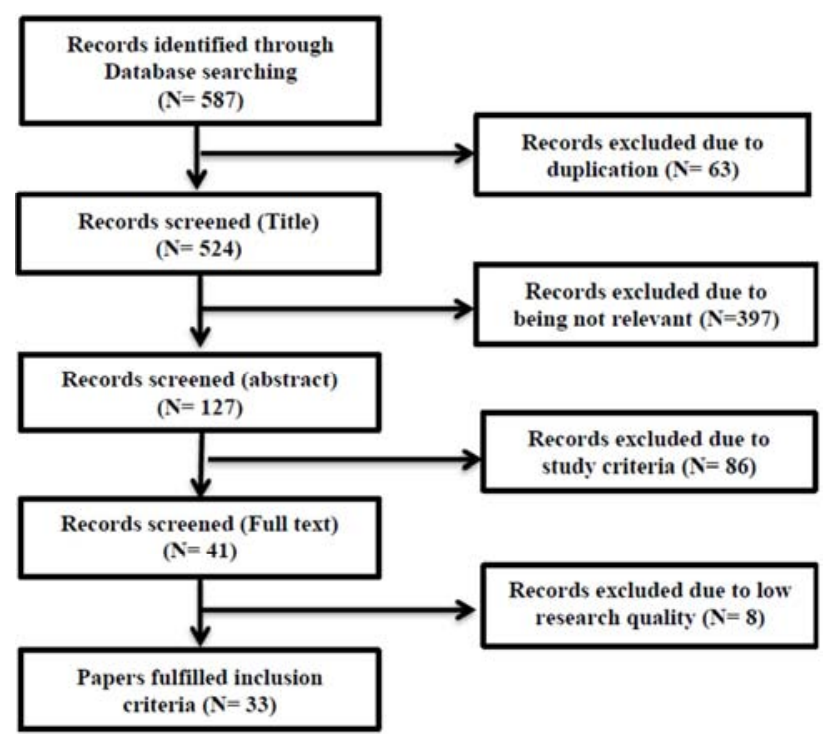

Figure 1. Article selection process.

\section{Results}

\subsection{General Information of the Studies}

As table 1 , shows majority of studies (58.4\%) were conducted between 2010 to 2016. USA Pacific countries such as Hawaii had highest number of studies (44\%) which followed by South Pacific (33.4\%) and Asia Pacific (16.6\%) countries. While majority of studies did not report the age of participants, adults and older people $(33.4 \%)$ were the most frequent age group which the studies were conducted among them. Half of studies did not report the gender of participants and $33.4 \%$ of studies were conducted among both male and female.

Table 1. General characteristics of the studies.

\begin{tabular}{lll}
\hline Factor & Frequency & Percentage \\
\hline Year of the studies & & \\
$2000-2004$ & 9 & 25 \\
$2005-2009$ & 6 & 16.6 \\
$2010-2016$ & 21 & 58.4 \\
Region & & \\
Asia Pacific & 6 & 16.6 \\
South Pacific Islands & 12 & 33.4 \\
Other countries & 2 & 5.5 \\
USA Pacific countries & 16 & 44.5 \\
Age of participants & & \\
Children \& Adolescents & 2 & 5.5 \\
Adults \& older & 11 & 30.6 \\
Older & 4 & 11.1 \\
Not stated & 19 & 52.8 \\
Gender of focused studies & & \\
Male & 2 & 5.5 \\
Female & 4 & 11.1 \\
Male/female & 12 & 33.4 \\
Not stated & 18 & 50 \\
\hline
\end{tabular}

The results of the study also showed that the pooled number of participants in these studies was included 6, 941,874 .

Majority of studies (86\%) applied the quantitative design and $14 \%$ used the qualitative design. However, $83 \%$ of 
studies did not report the sampling method, but random sampling was the most frequent sampling method (8\%). Amongst the studies that used quantitative study design, $36.1 \%$ used questionnaire for collecting the data while all of the qualitative studies $(8.3 \%)$ applied focus group and in-depth method for collecting the data (Table 2).

Table 2. Methodological characteristics of studies.

\begin{tabular}{lll}
\hline Factor & Frequency & Percentage \\
\hline Type of the studies & 33 & \\
Quantitative & 3 & 86 \\
Qualitative & & 14 \\
Sampling method & 3 & \\
Random & 1 & 8 \\
Convenience & 1 & 3 \\
Purposive & 1 & 3 \\
Snowball & 30 & 3 \\
Not Stated & & 83 \\
Data collection tool & 13 & \\
Questionnaire & 3 & 36.1 \\
Focus Group \& In-depth Interview & 20 & 8.3 \\
Not stated & & 55.6 \\
\hline
\end{tabular}

However $41,6 \%$ of studies did not mentioned the place of the studies, $25 \%$ of studies were conducted in community which followed by hospital based studies (13.8\%), health care based studies $(11.2 \%)$, and school based studies $(8.4 \%)$ (Figure 2)

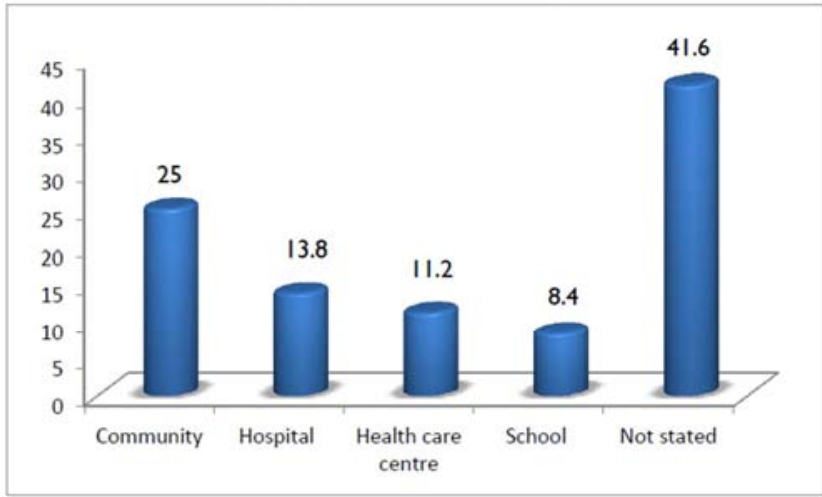

Figure 2. Frequency of studies based on the place of conducting.

\subsection{Determinant of Cancer}

Table 3 shows the common determinants for cancer in the Pacific region. Out of the 36 studies, 26 studies (72\%) listed the determinants of cancer. The common determinants for cancer were categorized into three areas including the services factors (11 studies), detection and treatment factors (8 studies), and individual factors ( 7 studies).

Low income status was reported as the most common determinant in service related factors $(11.1 \%)$ which was followed by lack of insurance $(8.33 \%)$, cost of services $(5.6 \%)$ and lack of access due to geographical location (5.6\%).

In detection and treatment related factors, unavailability of cancer detection methods such as screening, mammography, cholesterol screening, and bone densitometry was reported in 7 studies while inadequate treatment was only recorded in 1 study.
Unhealthy foods and dietary habits (13.8\%) and limited health education and awareness (5.6\%) were highlighted in the individual related factors of cancer.

Table 3. Determinant of Cancer.

\begin{tabular}{lll}
\hline Determinants & Frequency & Percentage \\
\hline Detection and Treatment Factors & & \\
Unavailability of cancer detecting method & 7 & 19.5 \\
Inadequate Treatment & 1 & 2.78 \\
Service Factors & & \\
Lack of insurances & 3 & 8.33 \\
Cost of services & 2 & 5.6 \\
Low income & 4 & 11.1 \\
Lack of accessibility (geographical location) & 2 & 5.6 \\
Individual Factors & & \\
Limited health education \& awareness & 2 & 5.6 \\
Unhealthy foods or dietary habits & 5 & 13.8 \\
\hline
\end{tabular}

\subsection{Prevention of Cancer}

Based on the prevention for cancer alone, 22 studies stated the most common prevention for cancer which focus on improving health care system (10 studies) such as screening, intensive follow up and surveillance, health education and awareness ( 8 studies), policy implementation ( 5 studies), and immunization ( 3 studies) as the least common prevention for cancer. Some factors listed above were mentioned in multiple studies.

\section{Discussion}

The aim of this study is to identify the common determinants and prevention for cancer in the Pacific in order to suggest some health promotion strategies that will improve and prevent cancer among pacific people in the future. The results show that available treatment, affordable services, and knowledge are the most common determinants of cancer in the Pacific countries. In addition, the results shows that the most common determinant of cancer included poor cancer detecting methods such as screening, mammography, and bone densitometry, unhealthy foods or dietary habits, and patients also received treatment based on their status. This was followed by type of affordable services and available services relating to cancer such as life insurance, cost of services, low salary, poverty and location. The least common determinants of cancer found by this study involved the limited knowledge about cancer in the Pacific.

Moreover it was found that $70 \%$ of deaths from cancer occur in low and middle income countries such as Pacific Islands Countries (PICs) [10]. There are numerous reasons as to why cancer deaths are higher in lower and middle income countries such as PICs but a majority appear to be due to the unavailability of services and as previously stated the lack of knowledge regarding the topic. Pacific islanders are regularly exposed to the risk factors for cancer, yet treatment and services are not available, accessible or even affordable for the individuals residing in the region [11]. In addition, developing countries have limited resources allocated toward prevention of cancer and treatment of cancer [12]. In PICs, 
cancer patients received better treatment and services when referred to the US and the other developed countries when compared to the patients receiving treatment and services within their own PICs [13].

The next determinant found by this study was that of poor knowledge. The total number of reviewed articles that measured Pacific islander's knowledge about cancer alone accounted for 2 articles out 36. Knowledge about cancer in the Pacific is the least common determinant in the Pacific yet it is one of the key strategies for cancer prevention [14]. Limited knowledge about cancer reduces the possibility of early detection. This in the long run can result in patients seeking advice at stages where the cancer is no longer treatable.

In addition to this poor communication between health specialists in the Pacific can result in poor knowledge among the population about the prevention of cancer [15]. In regards to the study participants in two of the analysed articles stated that if prior information about the cancer had been available patients would have been more likely to attempt to change their lifestyles and behaviour in an attempt to prevent the outcome [16]. Hence in order to improve and prevent cancer in the Pacific, good communication between health specialists and citizens should be prioritized and considered as a way for improving health and cancer prevention in the Pacific. This communication will be essential in the process of health promotion.

The next common determinant of cancer among pacific people was the availability and affordability of services including insurances policies. In a study conducted it was found that cancer patients from the Pacific island countries who have access to better health care services in the United States received cancer services based on their insurance status [17]. In regards to insurance status, people with insurance received good services and good treatment compared to those who did not have insurance [18]. Cost of cancer surgeries or services can vary depending on the types of services provided for them but cost of surgeries alone in cancer patients is very expensive [19]. Poverty is also one of the common determinants of cancer services in the Pacific. Pacific islands are categorized as middle and low income countries which show that poverty is evident in the pacific. According to LM Baldwin people living in rural areas appeared to receive less services when compared to those living in urban areas [11]. This shows that the types of services provided in the rural areas varies when compared to the services provided in the urban areas.

Furthermore another major issue identified was the poor screening and case identification methods present in the Pacific. Cancer detecting methods such as screening, mammography, cholesterol screening, and bone densitometry done among Pacific islanders are key tests for identifying various cancers. According to V Wong (2004), early cancer detecting methods similar to these are not accessible or available in certain places in the Pacific [20]. This shows that there is a large gap in the early detection stages and if targeted correctly can be beneficial to the treatment of cancer in the Pacific. Hence early detection is a necessary step to reducing the prevalence of cancer.

Lastly the most common prevention for cancer in the Pacific included immunization (HPV vaccines \& screening test followed by surveillance), health education or awareness, policy implementation, and improving health care system. According to the WHO, "between $30-50 \%$ of cancer can currently be prevented by avoiding risk factors and implementing existing evidence-based prevention strategies [1]. One way to address this issue is to by adapting some of the health promotion strategies such as PEN model in society in order to provide health services includes cancer and all types of services to the people of the Pacific living in rural areas and urban areas [21].

The study set out to investigate literature ranging from the year 2000 to 2017 in the hopes of strengthening the results and providing scope. However key limitations in this study were the absence of non-English literature and the omission of grey literature.

\section{Conclusion}

The results of this study show that cancer patients in the Pacific have limited knowledge about cancer. This also revealed however that services and treatment toward cancer are indeed available, accessible, and affordable in some areas in the Pacific. However for the countries where the services were not readily available, outside treatment appeared to be the most common source of treatment and cancer related services. Hence in order to improve the health and prevent cancer among pacific people, health specialist in PICs needs to address all these identified common determinants of cancer among cancer patients from the pacific in the past in order to come up with new strategies or prevention for cancer in the future.

Table 4. Data Extraction Sheet.

\begin{tabular}{|c|c|c|c|c|}
\hline & Study Information & Population & Methodology & Results \\
\hline 1 & $\begin{array}{l}\text { Untalan et al [22] } \\
\text { Year: } 2004 \\
\text { Type Of Study: Descriptive } \\
\text { study (cross-sectional) } \\
\text { Country: Hawaii }\end{array}$ & $\begin{array}{l}\text { Population: Total } 195 \\
\text { \# Of Male: } 116 \\
\text { \# Of Female: } 79 \\
\text { Age group: Ranges from } 0 \text { - } \\
19 \text { yrs. }\end{array}$ & $\begin{array}{l}\text { Place: Hospital } \\
\text { Sampling Method: Random } \\
\text { Data collection tools: Not } \\
\text { Stated }\end{array}$ & $\begin{array}{l}\text { Prevention } \\
\text { To improving the health care systems in both the } \\
\text { Pacific Islands and in Hawai'i. }\end{array}$ \\
\hline 2 & $\begin{array}{l}\text { Ou et al [23] } \\
\text { Year: } 2004 \\
\text { Type Of Study: Descriptive } \\
\text { study }\end{array}$ & $\begin{array}{l}\text { Population: } 237 \text { Cases } \\
\text { \# Of Male: } 93 \\
\text { \# Of Female: } 144 \\
\text { Age Group: } 41-50 \text { yrs. }\end{array}$ & $\begin{array}{l}\text { Place: Hospital } \\
\text { Sampling Method: Not Stated } \\
\text { Data collection tools: Interview }\end{array}$ & $\begin{array}{l}\text { Prevention } \\
\text { The implementation or existence of a national } \\
\text { comprehensive cancer control strategic plan } \\
\text { would facilitate greater identification, prevention, }\end{array}$ \\
\hline
\end{tabular}




\begin{tabular}{|c|c|c|c|c|}
\hline & Study Information & Population & Methodology & Results \\
\hline & Country: Kiribati & & & and treatment of cancer patients. \\
\hline 3 & $\begin{array}{l}\text { Ou et al [24] } \\
\text { Year; } 2004 \\
\text { Types Of Study: } \\
\text { Descriptive study } \\
\text { Country: Nauru }\end{array}$ & $\begin{array}{l}\text { Population: } 124 \\
\text { \# Of Male: } 46 \\
\text { \# Of Female: } 78 \\
\text { Age Group: Ranges from } 10 \\
-86 \text { yrs. }\end{array}$ & $\begin{array}{l}\text { Place: Hospital } \\
\text { Sampling Method: Not stated } \\
\text { Data collection tools: Not } \\
\text { stated }\end{array}$ & $\begin{array}{l}\text { Prevention } \\
\text { A national comprehensive cancer control strategic } \\
\text { plan and the implementation of that plan would } \\
\text { facilitate greater prevention, treatment and } \\
\text { control of cancer. } \\
\text { Determinant } \\
\text { Gender }\end{array}$ \\
\hline 4 & $\begin{array}{l}\text { Beltran et al [25] } \\
\text { Year: } 2016 \\
\text { Types Of Study: Cross- } \\
\text { Sectional study } \\
\text { Country: America }\end{array}$ & $\begin{array}{l}\text { Population: } 192 \\
\text { \# Males: } 71 \\
\text { \# Females: } 121 \\
\text { Age Group: Male } 19-62 \text { yrs } \\
\text { Females age ranges from } 18- \\
50 \text { yrs. }\end{array}$ & $\begin{array}{l}\text { Place: Not Stated } \\
\text { Sampling Method: Snowball } \\
\text { Data collection tools: Survey \& } \\
\text { Interviews }\end{array}$ & $\begin{array}{l}\text { Determinant } \\
\text { Ages } \\
\text { Prevention } \\
\text { Providing cancer education or awareness }\end{array}$ \\
\hline 5 & $\begin{array}{l}\text { Thompson et al [26] } \\
\text { Year: } 2014 \\
\text { Type Of Study: Cross- } \\
\text { Sectional } \\
\text { Country: America }\end{array}$ & $\begin{array}{l}\text { Population: } 800,000 \\
\text { \# Male: } 9363 \\
\text { \# Female: } 62543 \\
\text { Age Group: Men: ranges } \\
\text { from } 50-75 \text { years } \\
\text { Women ranges from 21-75 } \\
\text { years }\end{array}$ & $\begin{array}{l}\text { Place: Not Stated } \\
\text { Sampling Method: Not Stated } \\
\text { Data collection tools: Not } \\
\text { Stated }\end{array}$ & $\begin{array}{l}\text { Determinant } \\
\text { Ethnicity } \\
\text { Prevention } \\
\text { Language and gender concordant primary care } \\
\text { providers and culturally tailored online health } \\
\text { resources may help improve prevention cancer } \\
\text { screening in Asian Populations. }\end{array}$ \\
\hline 6 & $\begin{array}{l}\text { Foliaki et al [27] } \\
\text { Year: } 2014 \\
\text { Type Of Study: Cross- } \\
\text { Sectional study (Survey) } \\
\text { Country: Fiji }\end{array}$ & $\begin{array}{l}\text { Population: } 1261 \text { Cases } \\
\text { \# Male: } \\
\text { \# Female: } 1261 \\
\text { Age Group: Age ranges 16- } \\
64 \text { yrs. }\end{array}$ & $\begin{array}{l}\text { Place: Health Sub district } \\
\text { (Health care) } \\
\text { Sampling Method: Not Stated } \\
\text { Data collection tools: Not } \\
\text { stated }\end{array}$ & $\begin{array}{l}\text { Prevention } \\
\text { An on-going active education campaign } \\
\text { Future policy decision on the most appropriate } \\
\text { methods }\end{array}$ \\
\hline 7 & $\begin{array}{l}\text { Ka'ano'i et al [28] } \\
\text { Year: } 2004 \\
\text { Type Of Study: Cross- } \\
\text { Sectional (Survey) } \\
\text { Country: Hawaii }\end{array}$ & $\begin{array}{l}\text { Population: } 454 \\
\text { \# Male: Not stated } \\
\text { \# Female: Not stated } \\
\text { Age Group: Not stated }\end{array}$ & $\begin{array}{l}\text { Place: Health Care } \\
\text { Sampling Method: Not Stated } \\
\text { Data collection tools: } \\
\text { Questionnaire }\end{array}$ & $\begin{array}{l}\text { Prevention } \\
\text { Participation in cancer screening and prevention } \\
\text { activities }\end{array}$ \\
\hline 8 & $\begin{array}{l}\text { Tajima and Moore [16] } \\
\text { Year: } 2002 \\
\text { Type Of Study: Descriptive } \\
\text { Country: Asia Pacific }\end{array}$ & $\begin{array}{l}\text { Population: Not stated } \\
\text { \# Male: Not stated } \\
\text { \# Female: Not stated } \\
\text { Age Group: Not stated }\end{array}$ & $\begin{array}{l}\text { Place: Not Stated } \\
\text { Sampling Method: Not Stated } \\
\text { Data collection tools: Survey }\end{array}$ & $\begin{array}{l}\text { Prevention } \\
\text { Tobacco Control } \\
\text { Population-Based Prevention And Cancer Control } \\
\text { Cancer Knowledge Transfer And Dissemination } \\
\text { Building And Enhancing Capacity }\end{array}$ \\
\hline 9 & $\begin{array}{l}\text { Juon et al [29] } \\
\text { Year: } 2008 \\
\text { Type Of Study: Descriptive } \\
\text { Country: Asia Pacific in } \\
\text { America }\end{array}$ & $\begin{array}{l}\text { Population: } 1775 \\
\text { \#Male: } 619 \\
\text { \#Female: } \\
\text { Age Group: } 20-49 \text { yrs }\end{array}$ & $\begin{array}{l}\text { Place: Churches \& community } \\
\text { Sampling Method: Not stated } \\
\text { Data collection tools: Not } \\
\text { stated }\end{array}$ & $\begin{array}{l}\text { Prevention } \\
\text { Develop and implement culturally tailored } \\
\text { educational campaign }\end{array}$ \\
\hline 10 & $\begin{array}{l}\text { Garland et al [30] } \\
\text { Year: } 2008 \\
\text { Type Of study: Case } \\
\text { Studies } \\
\text { Country: Asia Pacific } \\
\text { Regions }\end{array}$ & $\begin{array}{l}\text { Population: } 3332258 \\
\text { \# Male: Not Stated } \\
\text { \# Female: Not stated } \\
\text { Age Group: Not stated }\end{array}$ & $\begin{array}{l}\text { Place: Not Stated } \\
\text { Sampling Method: Not Stated } \\
\text { Data collection tools: Not } \\
\text { Stated }\end{array}$ & $\begin{array}{l}\text { Prevention } \\
\text { Introduction of HPV Vaccine } \\
\text { Health Educating the Population about range of } \\
\text { sexual health issues, safe sex, good eating } \\
\text { behaviours, smoking. }\end{array}$ \\
\hline 11 & $\begin{array}{l}\text { Tsark [13] } \\
\text { Year: } 2007 \\
\text { Type Of Study: Descriptive } \\
\text { Country: US-associated } \\
\text { Pacific Island Countries }\end{array}$ & $\begin{array}{l}\text { Population: } \\
\text { \# Male: } \\
\text { \# Female: } \\
\text { Age Group: }\end{array}$ & $\begin{array}{l}\text { Place: Community ( } 4 \text { states) } \\
\text { Sampling Method: Not stated } \\
\text { Data collection tools: Survey }\end{array}$ & $\begin{array}{l}\text { Determinant } \\
\text { Over crowding } \\
\text { Poor Hygiene } \\
\text { Underdeveloped public works system } \\
\text { Foods have contributed to concurrent increase } \\
\text { obesity } \\
\text { Prevention } \\
\text { Seek Funding to expand cancer prevention and } \\
\text { control capacity in regionally appropriate ways. }\end{array}$ \\
\hline 12 & $\begin{array}{l}\text { Garland et al [31] } \\
\text { Year: } 2006 \\
\text { Type Of Study: Descriptive } \\
\text { Countries: } 175 \text { countries } \\
\text { world wide }\end{array}$ & $\begin{array}{l}\text { Population: } 175 \text { countries } \\
\text { \#Male: Not stated } \\
\text { \# Female: Not stated } \\
\text { Age Group: Not stated }\end{array}$ & $\begin{array}{l}\text { Place: Not Stated } \\
\text { Sampling Method: Not Stated } \\
\text { Data collection tools: Not } \\
\text { stated }\end{array}$ & $\begin{array}{l}\text { Determinant } \\
\text { Effect of Vitamin D on Ovarian risk } \\
\text { Oral contraceptive used } \\
\text { Sun exposure }\end{array}$ \\
\hline 13 & $\begin{array}{l}\text { Chelimo and Elwood [32] } \\
\text { Year: } 2015 \\
\text { Type Of Study: Descriptive } \\
\text { Country: New Zealand }\end{array}$ & $\begin{array}{l}\text { Population: } 6820 \\
\text { \# Male: } 2050 \\
\text { \# Female: } 4770 \\
\text { Age Group: Not stated }\end{array}$ & $\begin{array}{l}\text { Place: Health care centres } \\
\text { Sampling Method: Not stated } \\
\text { Data collection tools: Not } \\
\text { stated }\end{array}$ & $\begin{array}{l}\text { Determinant } \\
\text { Age } \\
\text { Gender }\end{array}$ \\
\hline 14 & Lee et al. [33] & Population: 33787 Cases & Place: Community & Prevention \\
\hline
\end{tabular}




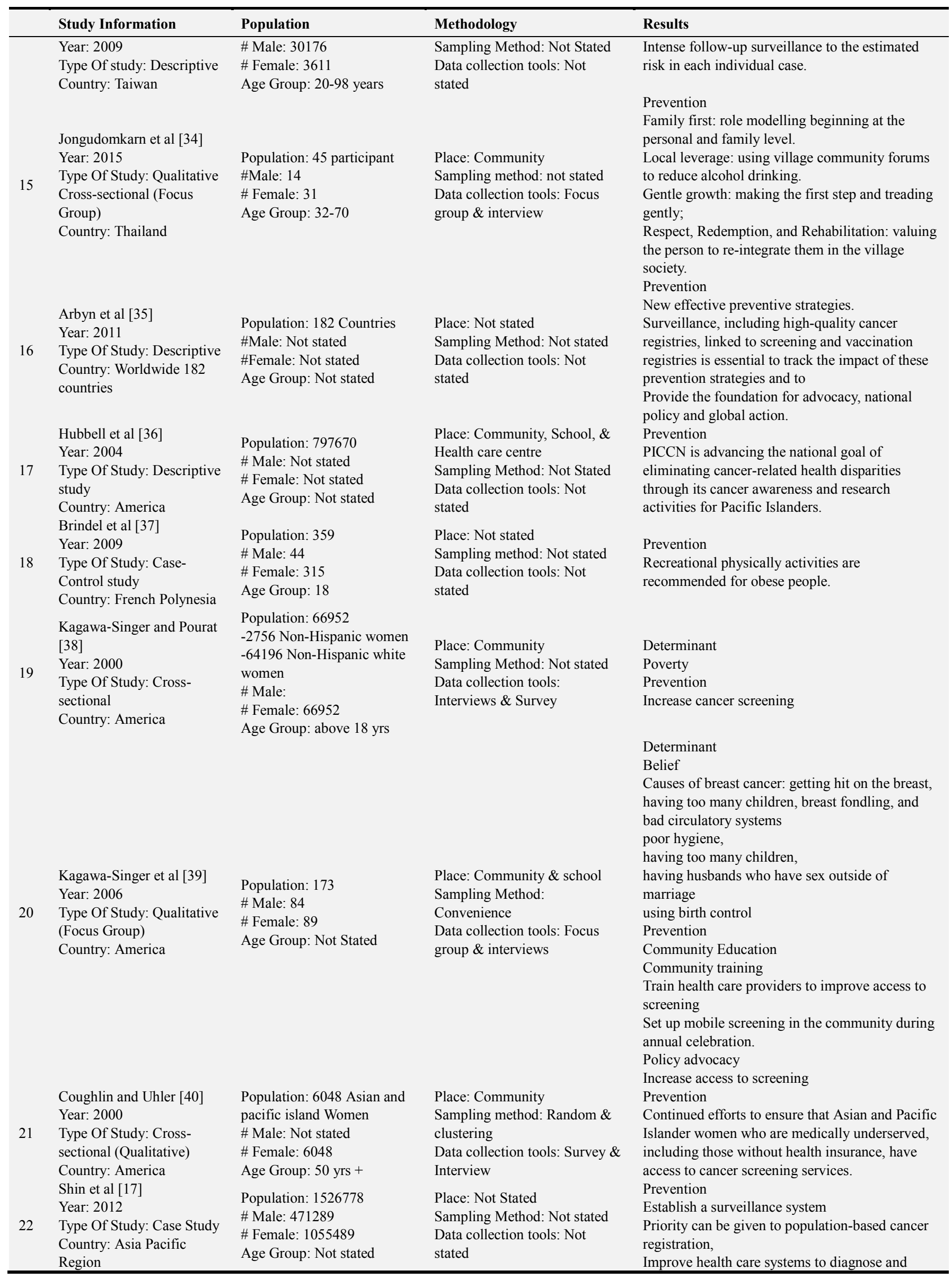




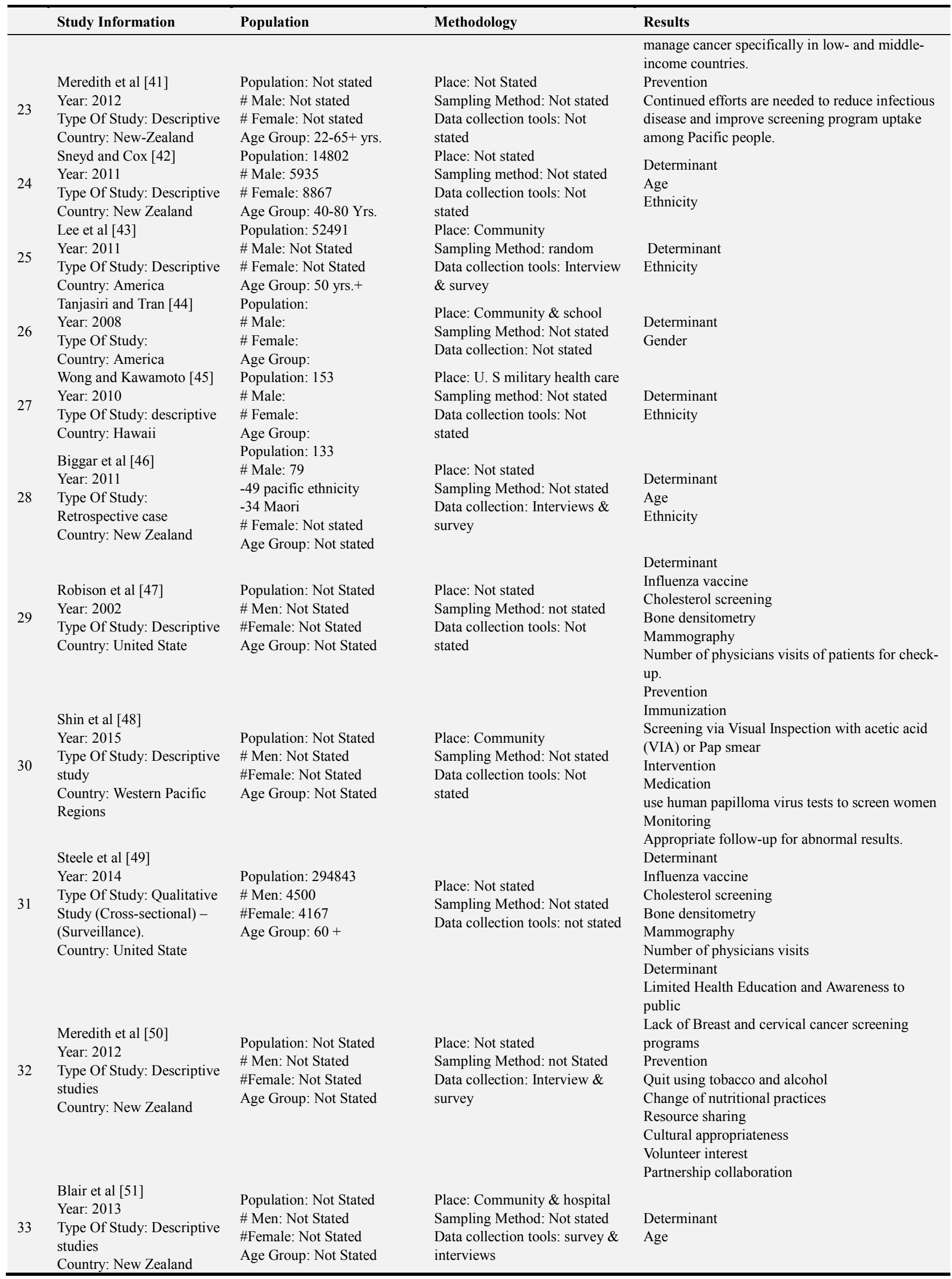




\begin{tabular}{lllll}
\hline \multicolumn{1}{c}{ Study Information } & Population & Methodology & Results \\
\hline \multirow{3}{*}{34} & Wu et al [52] & Total: 55 & Place: Communities & Determinant \\
Year: 2010 & Male: & Sampling Method: Purposive & Cost of services \\
& Type: Cohort Study & Female: 55 & Data collection tools: Focus & Participants received treatment from the hospital \\
& Country: American Samoa & Age: 19 \& older & groups & staffs depending on their status. \\
& Pobutsky et al [53] & Total: not Stated & Place: Communities & Determinants \\
Year: 2004 & Male: Not stated & Sampling Method: Not stated & No insurance \\
Study: Cohort & Female: Not stated & Data collection tools: Land & Low income \\
& Country: Hawaii (U. S) & Age: Not stated & based telephone survey & Lowucation \\
& Terada et al [54] & Total: 301 & Place: Hospital & \\
Year: 2016 & Male: Not stated & Sampling Method: Not stated & Determinant \\
Study: Cohort & Female: Not Stated & Data collection tools: Not & No Insurance \\
& Country: Hawaii & Age: $53.6 \pm 10.0$ & stated & \\
\hline
\end{tabular}

\section{References}

[1] WHO, Fact sheet No. 297: cancer. WHO Media Centre Fact Sheets, 2006.

[2] Farlex, The Free Dictionary by Farlex. Insolvency risk, retrieved on, 2015. 27.

[3] Stewart, B. W. and P. Kleihues, World cancer report. Vol. 57. 2003: IARC press Lyon.

[4] Well, E., et al., International childhood cancer day. Cancer Nursing Practice. 3 (1).

[5] Kuete, V., et al., Cytotoxicity of the methanol extracts of Elephantopus mollis, Kalanchoe crenata and 4 other Cameroonian medicinal plants towards human carcinoma cells. BMC Complementary and Alternative Medicine, 2017. 17 (1): p. 280.

[6] Wang, J. M., et al., Diet habits, alcohol drinking, tobacco smoking, green tea drinking, and the risk of esophageal squamous cell carcinoma in the Chinese population. European journal of gastroenterology \& hepatology, 2007. 19 (2): p. 171-176.

[7] Freeman, H. P., Poverty, culture, and social injustice: determinants of cancer disparities. CA: A Cancer Journal for Clinicians, 2004. 54 (2): p. 72-77.

[8] Friedenreich, C. M., Physical activity and cancer prevention: from observational to intervention research. Cancer epidemiology, biomarkers \& prevention: a publication of the American Association for Cancer Research, cosponsored by the American Society of Preventive Oncology, 2001. 10 (4): p. 287-301.

[9] Liu, J.-R., et al., Fresh apples suppress mammary carcinogenesis and proliferative activity and induce apoptosis in mammary tumors of the Sprague- Dawley rat. Journal of agricultural and food chemistry, 2008. 57 (1): p. 297-304.

[10] Gulland, A., Global cancer prevalence is growing at" alarming pace," says WHO. BMJ: British Medical Journal, 2014. 348 .

[11] Baldwin, L. M., et al., Access to cancer services for rural colorectal cancer patients. The Journal of Rural Health, 2008. 24 (4): p. 390-399.

[12] Ganz, P. A., et al., Supportive care after curative treatment for breast cancer (survivorship care): resource allocations in low-and middle-income countries. A Breast Health Global Initiative 2013 consensus statement. The Breast, 2013. 22 (5): p. 606-615.

[13] Tsark, J. U., Reducing cancer health disparities in the USassociated Pacific. Journal of public health management and practice: JPHMP, 2007. 13 (1): p. 49.

[14] Yoo, K.-Y., Cancer prevention in the Asia Pacific region. Asian Pac J Cancer Prev, 2010. 11 (4): p. 839-44.

[15] Thorne, S. E., B. D. Bultz, and W. F. Baile, Is there a cost to poor communication in cancer care?: a critical review of the literature. Psycho-oncology, 2005. 14 (10): p. 875-884.

[16] Tajima, K. and M. Moore, Programs for Asian Pacific cancer prevention in response to the four strategic directions of UICC for the new millennium. Asian Pacific J Cancer Prev, 2002. 3: p. 263-6.

[17] Shin, H.-R., M. C. Carlos, and C. Varghese, Cancer control in the Asia Pacific region: current status and concerns. Japanese journal of clinical oncology, 2012: p. hys077.

[18] Ayanian, J. Z., et al., The relation between health insurance coverage and clinical outcomes among women with breast cancer. New England Journal of Medicine, 1993. 329 (5): p. 326-331.

[19] Meropol, N. J. and K. A. Schulman, Cost of cancer care: issues and implications. Journal of Clinical Oncology, 2007. 25 (2): p. 180-186.

[20] Wong, V., et al., Cancer in the republic of Palau (Belau). Pac Health Dialog, 2004. 11 (2): p. 64-69.

[21] Scarinci, I. C., et al., Development of a theory-based (PEN-3 and health belief model), culturally relevant intervention on cervical cancer prevention among Latina immigrants using intervention mapping. Health Promotion Practice, 2012. 13 (1): p. 29-40.

[22] Untalan, F., et al., Disparities in outcomes for pediatric cancer patients treated in Hawai'i: comparing Hawai'i residents to children referred from the Pacific Islands. Pacific health dialog: a publication of the Pacific Basin Officers Training Program and the Fiji School of Medicine, 2004. 11 (2): p. 114-119.

[23] Ou, A. C., et al., Epidemiology of cancer in the Republic of Kiribati. Pacific health dialog, 2004. 11 (2): p. 88-93.

[24] Ou, A. C., et al., Epidemiology of cancer in the Republic of Nauru. Pacific health dialog, 2004. 11 (2): p. 101-106. 
[25] Beltran, R., et al., HPV Literacy and Associated Factors Among Hmong American Immigrants: Implications for Reducing Cervical Cancer Disparity. Journal of community health, 2016. 41 (3): p. 603-611.

[26] Thompson, C. A., et al., Patient and provider characteristics associated with colorectal, breast, and cervical cancer screening among Asian Americans. 2014, AACR.

[27] Foliaki, S., et al., Prevalence of HPV infection and other risk factors in a Fijian population. Infectious agents and cancer, 2014. 9 (1): p. 14.

[28] Ka'ano'i, M., K. Braun, and C. Gotay, Primary care physicians' knowledge, attitudes and practices related to cancer screening and cancer prevention clinical trials. Pacific health dialog, 2004. 11 (2): p. 160-165.

[29] Juon, H.-S., et al., Public health model for prevention of liver cancer among Asian Americans. Journal of community health, 2008. 33 (4): p. 199-205.

[30] Garland, S. M., et al., Recommendations for cervical cancer prevention in Asia Pacific. Vaccine, 2008. 26: p. M89-M98.

[31] Garland, C. F., et al., Role of ultraviolet B irradiance and vitamin $D$ in prevention of ovarian cancer. American journal of preventive medicine, 2006. 31 (6): p. 512-514.

[32] Chelimo, C. and J. M. Elwood, Sociodemographic differences in the incidence of oropharyngeal and oral cavity squamous cell cancers in New Zealand. Australian and New Zealand journal of public health, 2015. 39 (2): p. 162-167.

[33] Lee, K.-D., et al., The incidence and risk of developing a second primary esophageal cancer in patients with oral and pharyngeal carcinoma: a population-based study in Taiwan over a 25 year period. BMC cancer, 2009.9 (1): p. 373.

[34] Jongudomkarn, D., P. Singhawara, and C. Macduff, Village voices: lessons about processes for disease prevention from a qualitative study of family health leaders in a community in northeastern Thailand. Asian Pacific journal of cancer prevention, 2015. 16 (10): p. 4401-4408.

[35] Arbyn, M., et al., Worldwide burden of cervical cancer in 2008. Annals of oncology, 2011. 22 (12): p. 2675-2686.

[36] Hubbell, F., et al., Addressing the cancer control needs of Pacific Islanders: experience of the Pacific Islander Cancer Control Network. Pacific health dialog, 2004. 11 (2): p. 233238.

[37] Brindel, P., et al., Anthropometric factors in differentiated thyroid cancer in French Polynesia: a case-control study. Cancer Causes \& Control, 2009. 20 (5): p. 581-590.

[38] Kagawa-Singer, M. and N. Pourat, Asian American and Pacific Islander breast and cervical carcinoma screening rates and healthy people 2000 objectives. Cancer, 2000. 89 (3): p. 696-705.

[39] Kagawa-Singer, M., et al., Breast and cervical cancer control among Pacific Islander and Southeast Asian Women: participatory action research strategies for baseline data collection in California. Journal of Cancer Education, 2006. 21.
[40] Coughlin, S. S. and R. J. Uhler, Breast and cervical cancer screening practices among Asian and Pacific Islander women in the United States, 1994-1997. Cancer Epidemiology and Prevention Biomarkers, 2000.9 (6): p. 597-603.

[41] Meredith, I., et al., Cancer in Pacific people in New Zealand. Cancer Causes \& Control, 2012. 23 (7): p. 1173-1184.

[42] Sneyd, M. J. and B. Cox, Clinical and histologic factors associated with melanoma thickness in New Zealand Europeans, Maori, and Pacific peoples. Cancer, 2011. 117 (11): p. 2489-2498.

[43] Lee, H. Y., et al., Colorectal cancer screening disparities in Asian Americans and Pacific Islanders: which groups are most vulnerable? Ethnicity \& health, 2011. 16 (6): p. 501-518.

[44] Tanjasiri, S. P. and J. H. Tran, Community capacity for cancer control collaboration: weaving an Islander network for cancer awareness, research and training for Pacific Islanders in Southern California. Cancer detection and prevention, 2008. 32 (1): p. 37-40.

[45] Wong, V. S. and C. T. Kawamoto, Understanding cervical cancer prevention and screening in Chuukese women in Hawaii. Hawaii Med J, 2010. 69 (6 Suppl 3): p. 13-16.

[46] Biggar, M., et al., Gastric cancer location and histological subtype in Pacific people and Maori defies international trends. The New Zealand Medical Journal (Online), 2011. 124 (1331).

[47] Robison, S. W., et al., Ethnic differences in survival among Pacific Island patients diagnosed with cervical cancer. Gynecologic oncology, 2002. 84 (2): p. 303-308.

[48] Shin, H.-R., et al., Prevention of infection-related cancers in the WHO Western Pacific Region. Japanese journal of clinical oncology, 2015: p. hyv092.

[49] Steele, C. B., et al., Physician visits and preventive care among Asian American and Pacific Islander long-term survivors of colorectal cancer, USA, 1996-2006. Journal of Cancer Survivorship, 2014. 8 (1): p. 70-79.

[50] Meredith, I., et al., High rates of endometrial cancer among Pacific women in New Zealand: the role of diabetes, physical inactivity, and obesity. Cancer Causes \& Control, 2012. 23 (6): p. $875-885$.

[51] Blair, V., A. Kahokehr, and T. Sammour, Cancer in Māori: lessons from prostate, colorectal and gastric cancer and progress in hereditary stomach cancer in New Zealand. ANZ journal of surgery, 2013.83 (1-2): p. 42-48.

[52] Wu, L., et al., American Samoan women's health: experiences and attitudes toward breast and cervical cancer screening. Hawaii medical journal, 2010. 69 (6 Suppl 3): p. 17.

[53] Pobutsky, A., et al., Community based participatory approaches to address health disparities in Hawai'i: recent applications in cancer prevention, detection and treatment programs. Pacific health dialog, 2004. 11 (2): p. 183-190.

[54] Terada, K., et al., Health Disparities in Native Hawaiians and Other Pacific Islanders Following Hysterectomy for Endometrial Cancer. Hawai'i Journal of Medicine \& Public Health, 2016. 75 (5): p. 137. 